\title{
EVEKTIVITAS PENGGUNAAN PUPUK ORGANIK HAYATI DAN CEDAWAN MIKORIZA ARBUSKULA (CMA) TERHADAP PRODUKTIVITAS TANAMAN TERUNG HIJAU (Solanum melongena)
}

\author{
Rohikim Mahtum1, Diah Sudiarti2, Imam Bukhori Muslim3. \\ 123Pendidikan Biologi, Universitas Islam Jember \\ 1rohikim20@gmail.com,2diah.sudiarti23@gmail.com,3ib3721083@gmail.com
}

\begin{abstract}
ABSTRAK
Terung Hijau (Solanum melongena L.) adalah tanaman pangan yang ditanam untuk dimanfaatkan buahnya. Penelitian ini menggunakan rancangan acak lengkap dengan pola empat perlakuan. Pertama menggunakan $\mathrm{POH}$, kedua $\mathrm{POH}$ dan $\mathrm{CMA}$, ketiga kontrol positif, dan keempat kontrol negatif. Setiap perlakuan dilakukan pengulangan sebanayak tiga kali. Berdasarkan hasil penelitian diperoleh data yaitu dengan rata-rata terbaik untuk jumlah buah 0,80 (POH), 1,02 (POH dan CMA), 1,44 (K+), 0,97 (K-), berat basah 48,33 (POH), 58,06 (POH dan CMA), 71,11 (K+), 62,22 (K-), dan berat kering 26,39 (POH), 31,67 (POH dan CMA), 42,78 (K+), $30,56$ (K-). Berdasarkan hasil uji statistik untuk jumlah buah 0,154 ( $\alpha>0,05)$, berat basah 0,331 $(a>0,05)$, berat kering $0,138(a>0,05)$. Dari hasil uji statistik tersebut dapat disimpulkan bahwa pemberian $\mathrm{POH}$ dan $\mathrm{CMA}$ tidak berpengaruh nyata terhadap produktivitas terung hijau, sehingga pemberian $\mathrm{POH}$ dan CMA tidak efektif terhadap produktivitas terung hijau.

Kata Kunci: Pupuk Organik Hayati, Cendawan Mikoriza Arbuskula, Tanaman Terung Hijau (Solanum melongena L.)

ABSTRACT

Green Eggplant (Solanum melongena L.) is a food crop that is planted for fruit use. This study uses a completely randomized design with a four treatment pattern. First using $\mathrm{POH}$, second $\mathrm{POH}$ and $\mathrm{CMA}$, third positive control, and fourth negative control. Each treatment was repeated three times. Based on the results of the study obtained data with the best average for the number of fruit is $0.80(\mathrm{POH}), 1.02(\mathrm{POH}$ and CMA), $1.44(\mathrm{~K}+), 0.97$ (without fertilizer), wet weight 48, $33(\mathrm{POH}), 58.06(\mathrm{POH}$ and $\mathrm{CMA}), 71.11(\mathrm{~K}+), 62.22$ (without fertilizer), and dry weight $26.39(\mathrm{POH}), 31.67(\mathrm{POH}$ and $\mathrm{CMA}), 42,78(\mathrm{~K}+), 30.56$ (without fertilizer). Based on the results of statistical tests for the number of fruit $0.154(a>0.05)$, wet weight $0.331(a>0.05)$, dry weight $0.138(a>0.05)$. With the results of these statistical tests it can be concluded that the administration of $\mathrm{POH}$ and $\mathrm{CMA}$ has no significant effect on the productivity of green eggplants, so the administration of $\mathrm{POH}$ and $\mathrm{CMA}$ is not effective on the productivity of green eggplant.
\end{abstract}

Keyword: Biological Organic Fertilizers (BOF), Arbuscular Mycorrhizal Fungi, Green Eggplant Plants (Solanum melongena L.) 


\section{Pendahuluan}

Indonesia merupakan negara agraris yang sebagian besar wilayah negaranya digunakan untuk lahan pertanian. Salah satu jenis hasil pertanian di Indonesia ialah terung hijau (Solanum melongena L). Terung Hijau hijau dapat tumbuh sampai ketinggian sekitar $1000 \mathrm{~m} \mathrm{dpl}$, tetapi di dataran rendah tumbuhnya lebih cepat. Suhu yang paling cocok untuk tanaman terung adalah 25-30oC dengan perbedaan sedikit antara suhu siang dan malam (Nugrahandi, 2016).

Pupuk organik hayati (PO) merupakan pupuk dari bahan organik yaitu dari residu tanaman, pupuk hijau, pupuk kandang, juga meliputi mikroba seperti bakteri dan jamur. Pupuk organik hayati mempunyai keunggulan dalam meningkatkan produksi tanaman dan memelihara kesuburan tanah secara berkelanjutan (Suliasih, 2015).

Cendawan mikoriza arbuskula (CMA) merupakan suatu cendawan yang hidup secara simbiosis mutualisme dengan akar tanaman. Cendawan mikoriza arbuskula bermanfaat bagi tanaman terutama dalam meningkatkan penyerapan unsur hara, meningkatkan ketahanan tanaman terhadap kekeringan, dan ketahanan terhadap serangan patogen akar (Bertham, Rr, et al., dalam Sudiarti, 2018). Penelitian ini dilakukan untuk mengetahui efektivitas penggunaan pupuk organisme hayati $(\mathrm{POH})$ dan cendawan mikoriza arbuskula (CMA) terhadap produkrivitas tanaman terung hijau (Solanum melongena L.). Untuk mencapai produktivitas

tanaman terung hijau (Solanum melongena L.) yang tinggi, maka perlu adanya inovasi teknologi budidaya yang sesuai dengan kondisi lingkungan yang ada. Cara meningkatkan produktivitas tanaman terung hijau antara lain dengan melakukan pemupukan.

Jenis pupuk yang sering digunakan dalam penanaman terung hijau adalah jenis pupuk kimia. Penggunaan bahan-bahan kimia berupa pupuk yang melebihi dosis, hal ini menimbulkan masalah cukup serius dengan harga pasaran yang mahal dan pupuk kimia juga berbahaya bagi lingkungan (Syaifudin et al, 2010).

Oleh karena itu peneliti memunculkan suatu inovasi dengan menggunakan pupuk alternatif yaitu dengan pemberian pupuk organik hayati $(\mathrm{POH})$ dan Cendawan mikoriza arbuskula (CMA) untuk meningkatkan produktivitas tanaman terung hijau, sehingga penggunaan pupuk alternatif ini dapat efektif terhadap produktivitas tanaman terung hijau (Solanum melongena $\mathrm{L}$.) 


\section{Metode Penelitian}

Jenis penelitian ini adalah penelitian eksperimen dengan tanaman terung hijau (Solanum melongena L.) sebagai objek penelitian.

Percobaan ini dilakukan dengan menggunakan rancangan acak lengkap (RAL) dengan pola empat perlakuan. Parameter pengamatan meliputi : Jumlah buah pertanaman, berat basah pertanaman, dan berat kering.

\section{Metode Pengumpulan Data}

Rancangan percobaan pengumpulan data dalam penelitian ini menggunakan rancangan acak lengkap (RAL).

a. Alat dan Bahan

Alat yang digunakan adalah Timba, Oven, Timbangan digital, Alat Tulis, Pisau Atau Gunting, SmartPhone, Kalender, lembar tabel pengamatan. Bahan yang digunakan adalah tanaman terung hijau (Solanum melongena L.) Pupuk organik hayati $(\mathrm{POH})$, Cendawa mikoriza arbuskula (CMA), Pupuk NPK.

b. Prosedur Kerja Tahap persiapan

1. Menyiapkan alat dan bahan serta lahan seluas $5 \times 6 \mathrm{~m} 2$.

2. Menyiapkan bahan yang digunakan dalam penelitian ini adalah Pupuk Organik Hayati (POH), Cendawa Mikoriza Arbuskula (CMA), Pupuk
NPK, Tanaman terung hijau (Solanum melongena L.)

\section{Tahap Pemanenan}

Panen pertama terung hijau (Solanum melongena L) dilakukan saat tanaman berumur 50-65 hst atau 15-20 hst munculnya bunga. Kriteria panen buah terung layak panen adalah daging belum keras, warna buah mengkilat, ukuran tidak terlalu besar atau kecil. Pemanenan dapat dilakukan seminggu sekali, sehingga total dalam satu musim dapat di lakukan $8 x$ panen dengan potensi jumlah buah pertanaman bisa mencapai 21 buah.

\section{Tahap Pengamatan}

- Pengamatan dilakukan 51 hari setelah tanam

- Pengamatan meliputi:

a. Penghitungan dan pengamatan dilakukan secara periodik $1 x$ dalam 1 minggu yaitu : jumlah buah pertanaman b. Tambahan pengamatan: tanaman siap panen pada usia berapa.

c. Penimbangan hasil panen tanaman terung hijau (Solanum melongena) meliputi : berat basah tanaman dan berat kering tanaman.

\section{Metode Analisis Data}

Penelitian ini data dianalisis menggunakan Analysis of Vaeriance (ANOVA) menggunakan SPSS 20.0. Data yang diamati terdiri atas jumlah 
buah pertanaman, berat basah, dan berat kering. Pengamatan jumlah buah dilakukan pada saat tanaman berusia 51, 58, 65, 72, 79 hst (hari setelah tanam). Pengamatan berat basah dilakukan 65, 72 hst (hari setelah tanam) atau panen pertama dan kedua. Pengamatan berat kering dilakukan 72, 79 hst (hari setelah tanam).

\section{Pembahasan}

Penelitian ini dilakukan mulai tanggal 18 Agustus 2019 sampai 15 September 2019 di lahan Pusat Penelitian dan Pengembangan Program Studi Pendidikan Biologi Fakultas Keguruan dan Ilmu Pendidikan Universitas Islam Jember, Jl. Ikan Kakap Kebonagung, Kec. Kaliwates, Kab. Jember. Sampel tanaman terung yang digunakan merupakan Varietas Hitavi F1 yang sudah berumur 51 hari setelah tanam (hst). Terung hijau jenis Hitavi F1 ini memiliki karakteristik yang secara genetik memiliki ketahanan terhadap penyakit layu bakteri dan virus gemini. Pada saat tanaman berusia 45 hst (hari setelah tanam) muncul bunga yang akan menjadi calon buah, kemudian bunga menjadi buah pada saat tanaman berusia 51 hst (hari setelah tanam) dilakukan pengambilan data yang meliputi Jumlah buah, berat basah, dan berat kering.

Pemanenan buah terung dilakukan saat tanaman berusia 65-75 hst (hari setelah tanam), hasil panen buah terung ditimbang untuk mengetahui berat basah buah. Kemudian buah terung hasil dari penimbangan berat basah di jemur selama 3hari untuk membuat terung menjadi layu, setelah buah terung layu dilakukan pengovenan sampai kadar air buah terung menurun, dan selanjutnya dilakukan penimbangan kembali untuk mengetahui berat kering buah.

Pengamatan terhadap Jumlah Buah Terung Hijau (Solanum melongena L.)

Tabel 1. Data Jumlah Buah Terung Hijau (Solanum melongena L.)

\begin{tabular}{ccccccc}
\hline \multirow{2}{*}{ Perlakuan } & 51 & 58 & 65 & 72 & 79 & rata- \\
& & & & & & \\
& hst & hst & hst & hst & hst & rata \\
\hline POH & 0,11 & 0,88 & 1 & 1 & 1 & 0,8 \\
POH+CMA & 0,56 & 1 & 1,22 & 1,11 & 1,22 & 1,02 \\
K + & 0,78 & 1,22 & 1,33 & 1,77 & 2,11 & 1,44 \\
K - & 0,56 & 0,88 & 1 & 1.33 & 1,44 & 0,97 \\
& & & & & & \\
\hline
\end{tabular}

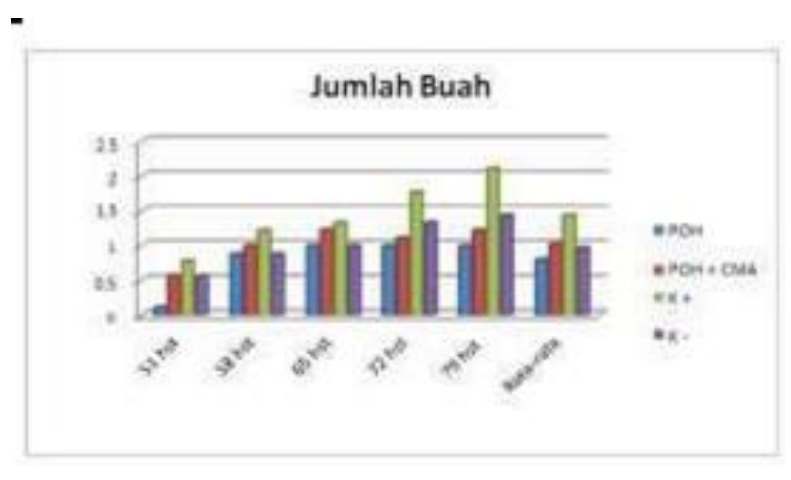

Gambar 1. Grafik jumlah buah terung hijau (Solanum melongena L.) 
Berdasarkan data diatas diketahui bahwa pemberian pupuk NPK, terhadap jumlah buah terung hijau lebih baik dibandingkan dengan pemberian $\mathrm{POH}$, serta kombinasi dari $\mathrm{POH}$ dan CMA, dan tanpa pemberian pupuk. Pengamatan terhadap Berat Basah Terung Hijau (Solanum melongena L.) Dapat diamati pada tabel dibawah ini:

Tabel 2. Data Berat Basah Terung Hijau (Solanum melongena L.)

\begin{tabular}{cccc}
\hline Perlakuan & 65 hst & 72 hst & $\begin{array}{c}\text { Rata- } \\
\text { rata }\end{array}$ \\
\hline POH & 11,11 & 85,55 & 48,33 \\
POH+CMA & 66,11 & 50 & 58,06 \\
K + & 120 & 22,22 & 71,11 \\
K - & 67,77 & 56,66 & 62,22 \\
\hline
\end{tabular}

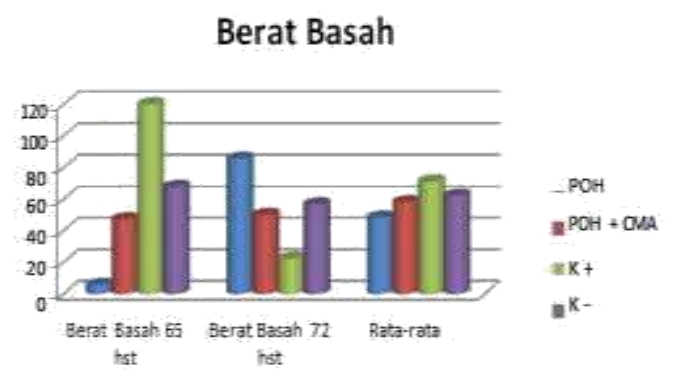

Gambar2. Grafik berat basah terung hijau (Solanum melongena L.)

Berdasarkan data diatas diketahui bahwa pemberian pupuk NPK, terhadap berat basah buah terung hijau lebih baik dibandingkan dengan pemberian $\mathrm{POH}$, serta kombinasi dari $\mathrm{POH}$ dan CMA, dan tanpa pemberian pupuk.
Pengamatan terhadap Berat Kering Terung Hijau (Solanum melongena L.)

Tabel 3. Data Berat Kering Terung Hijau (Solanum melongena L.)

\begin{tabular}{cccc}
\hline Perlakuan & 72 hst & 79 hst & Rata rata \\
\hline POH & 5,56 & 47,22 & 26,39 \\
POH+CMA & 34,44 & 28,89 & 31,67 \\
K + & 63,33 & 22,22 & 42,78 \\
K - & 34,44 & 26,67 & 30,56 \\
& & & \\
\hline
\end{tabular}

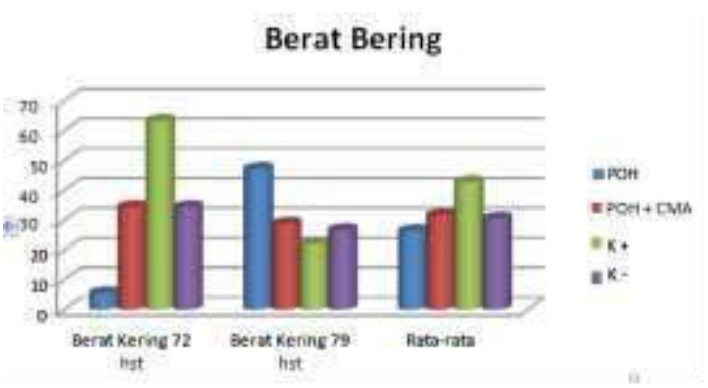

Gambar 3. Grafik berat kering terung hijau (Solanum melongena L.)

Berdasarkan data diatas diketahui bahwa pemberian pupuk kontrol positif (NPK), terhadap berat kering buah terung hijau lebih baik dibandingkan dengan pemberian $\mathrm{POH}$, serta kombinasi dari $\mathrm{POH}$ dan CMA, dan tanpa pemberian pupuk.

Pengamatan terhadap Jumlah Buah, Berat Basah, dan Berat Kering Terung Hijau (Solanum melongena L.). 
Tabel 4. Rata-rata nilai terbaik di setiap perlakuan terhadap produktivitas

\begin{tabular}{cccc}
\hline $\begin{array}{c}\text { Terung } \\
\text { melongena L.) }\end{array}$ & Hijau & (Solanum \\
& & & \\
\hline Perlakuan & Jumlah & Berat & Berat \\
& buah & basah & kering \\
\hline POH & 0,8 & 48,33 & 26,39 \\
POH + CMA & 1,02 & 58,06 & 31,67 \\
Kontrol + & 1,44 & 71,11 & 42,78 \\
Kontrol - & 0,97 & 62,22 & 30,56 \\
\hline
\end{tabular}

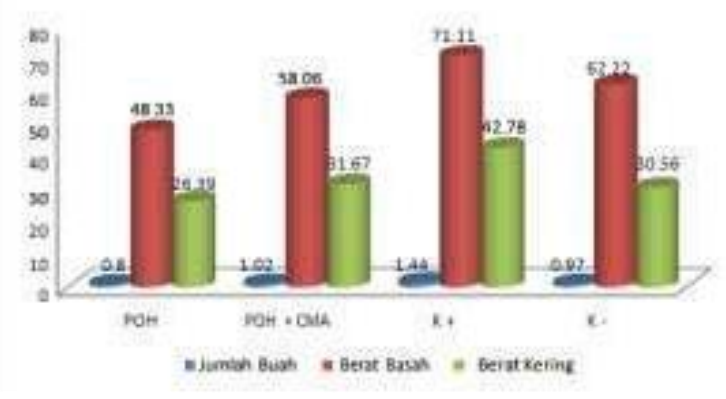

Gambar 4. Grafik Rata-rata Nilai Terbaik Disetiap Perlakuan terhadap Produktivitas Terung Hijau (Solanum melongena L.)

Berdasarkan data diatas perlakuan terbaik adalah pupuk NPK, dibandingkan dengan pemberian $\mathrm{POH}$, $\mathrm{POH}$ dan CMA dan tanpa pemberian pupuk.
Tabel 5. Data Hasil Uji one way anova terhadap Perlakuan $\mathrm{POH}$ dan CMA, Kontrol positif (NPK), Kontrol negatif (tanpa perlakuan).

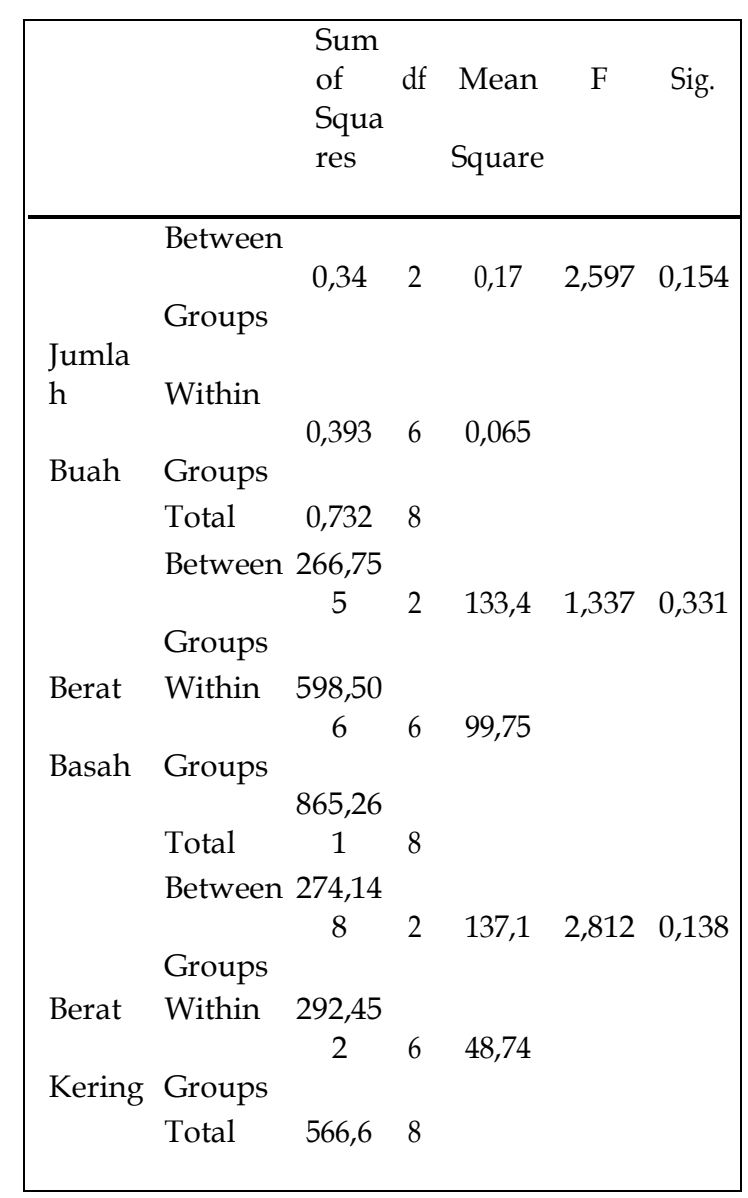

Berdasarkan data diatas uji one way Anova diperoleh nilai $\mathrm{F}$ hitung sebesar 2,597 dengan nilai signifikansi 0,154 untuk jumlah buah, 1,337 dengan nilai signifikansi 0,331 untuk berat basah, dan 2,812 dengan nilai signifikansi 0,138 untuk berat kering, pada semua perlakuan terhadap produktivitas tanaman terung hijau. Mengingat nilai signifikansi 0,154 (jumlah buah) lebih besar dari 0,05 ( $a>0,050), 0,331$ (berat basah) lebih besar 
dari 0,05 ( $a>0,050), 0,138$ (jumlah berat kering) lebih besar dari 0,05 ( $a>0,050)$ maka dapat disimpulkan bahwa pemberian $\mathrm{POH}$ dan CMA tidak berpengaruh nyata terhadap produktivitas tanaman terung (Solanum melongena L.), sehingga tidak dilanjutkan ke uji duncan.

Tabel 6. Data Hasil Uji one way anova terhadap terhadap Perlakuan $\mathrm{POH}$, Kontrol+ (NPK), Kontrol - (tanpa perlakuan).

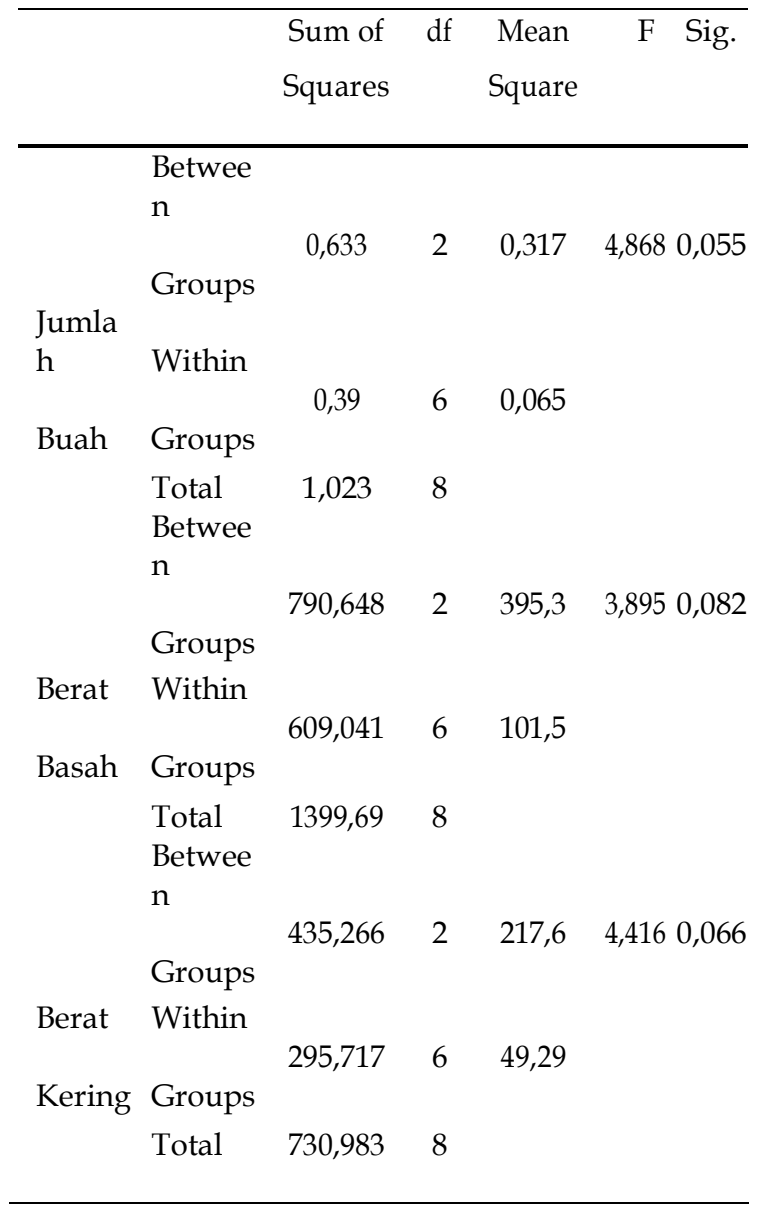

Berdasarkan data diatas uji one way Anova diperoleh nilai $F$ hitung sebesar 4,868 dengan nilai signifikansi 0,055 untuk jumlah buah, 3,895 dengan nilai signifikansi 0,82 untuk berat basah, dan 4,416 dengan nilai signifikansi 0,66 untuk berat kering, pada semua perlakuan terhadap produktivitas tanaman terung hijau. Mengingat nilai signifikansi 0,055 (jumlah buah) lebih besar dari 0,05 ( $a>0,050), 0,82$ (berat basah) lebih besar dari 0,05 ( $a>0,050)$, 0,66 (jumlah berat kering) lebih besar dari $0,05 \quad(a>0,050)$ maka dapat disimpulkan bahwa pemberian $\mathrm{POH}$ dan CMA berpengaruh nyata terhadap jumlah buah terung (Solanum melongena L.), sehingga dilanjutkan ke uji Duncan. Sedangkan untuk berat basah dan berat kering tidak berpengaruh nyata, sehingga tidak dilanjutkan uji Duncan.

Tabel 7. Data Hasil Uji Duncan jumlah buah terhadap perlakuan $\mathrm{POH}$, Kontrol+ (NPK), Kontrol-(tanpa perlakuan).

\begin{tabular}{|lccc|}
\hline Perlakuan & $\mathrm{N}$ & \multicolumn{2}{r|}{ Subset for alpha $=$} \\
& & 0.05 & \\
& & 1 & 2 \\
& & \\
\hline POH & 3 & 0,8 & \\
Kontrol - & 3 & 1,0433 & 1,0433 \\
Kontrol + & 3 & & 1,4433 \\
Sig. & & 0,287 & 0,103 \\
\hline
\end{tabular}


Berdasarkan data diatas uji Duncan diketahui bahwa pemberian $\mathrm{POH}$ berbeda nyata dengan $\mathrm{K}+$ tetapi tidak berbeda nyata dengan K-. Dalam penelitian ini salah satu faktor penting yang menyebabkan tidak berpengaruh nyata pada hasil yang didapatkan yaitu : faktor cuaca dan air pada tempat penelitian, yang memberi perbedaan fotosintesis tiap tanaman dan air yang didapatkan oleh tanaman. Selama penelitian ini berjalan, cuaca yang berubah-ubah dan kondisi air yang tidak mencukupi sehingga menyebabkan proses fotosintesis tiap tanaman sulit untuk bekerja secara optimal. Adanya hama serangga, yaitu semut hitam, belalang, dan gulma tanaman, yaitu rumput ikut memberi dampak negatif terhadap produktivitas tanaman terung hijau (Solanum melongena L) mulai dari persaingan memperebutkan tempat untuk tumbuh, sinar matahari, air dan nutrisi dalam tanah untuk gulma tanaman, hingga merusak daun dan batang tanaman untuk digunakan sebagai makanan dan tempat bersarang untuk serangga.

Faktor lokasi penanaman pada tempat penelitian juga ikut memberi perbedaan terhadap fotosintesis dan air yang didapatkan oleh tanaman terung hijau (Solanum melongena L). Pada akhirnya produktivitas tanaman berjalan tidak optimal, Seperti pada parameter jumlah buah, berat basah, dan berat kering, maka hasil yang didapatkan kurang maksimal sehingga dari hasil penelitian dapat dikatakan bahwa pemberian kombinasi pupuk $\mathrm{POH}$ dan CMA tidak berpengaruh nyata terhadap produktivitas tanaman terung hijau (Solanum melongena L). Sehingga pupuk $\mathrm{POH}$ dan CMA tidak efektif terhadap produktifitas tanaman terung hijau.

\section{Kesimpulan dan Saran}

a. Simpulan

Berdasarkan penelitian yang telah dilakukan, maka dapat dirumuskaan kesimpulan sebagai berikut :

Penggunaan kombinasi Pupuk Organik Hayati $(\mathrm{POH})$ dan Cendawan Mikoriza Arbuskula (CMA) tidak efektif terhadap produktivitas tanaman terung hijau (Solanum melongena L.)

b. Saran

Untuk peneliti lanjut yang ingin menganalisis produktivitas tanaman terung hijau (Solanum melongena L.), diharapkan dilakukan di tempat yang memiliki $\mathrm{pH}$ tanah bagus. Pilih tempat dan waktu atau musim yang sesuai agar jumlah air yang diperlukan bisa lebih optimal.

\section{Daftar Pustaka}

Angio Melisnawati H. 2016. Respon Fisiologi Dan Morfologi Tanaman Terung (Solanum Melongena) terhadap Cekaman Suhu Tinggi. Sekolah Pascasarjana Institut Pertanian Bogor. Bogor 
Arya Listyan Nugrahandi, Dkk. 2016. Uji Formulasi Berbagai Mol Organik Terhadap Pertumbuhan Dan Hasil Tanaman Terong (Solanum Melongena L.). Plumula Volume 5 No. 2

Indriyani Titis .2017. Pengaruh Penyiangan Gulma dan Dua Varietas terhadap Pertumbuhan dan Hasil Terong (solanum melongena), Argoteknologi, Fakultas Prtanian. Universitas Muhammadiyah Purwokerto.

Juhaeti dan Lestari. 2016. Pertumbuhan, Produksi dan Potensi Gizi Terong Asal Enggano pada Berbagai Kombinasi Perlakuan Pemupukan. Volume 15 Nomor 3. ISSN 0126-1754.

Karnedi Dieng. 2017. Pengaruh Waktu Pemberian Cendawan Mikoriza Arbuskular (Cma) Terhadap Pertumbuhan Koro Hijau (Macrotyloma Uniflorm) Sebagai Tumbuhan Pionir Pengembali Kesuburan Tanah Bekas Tambang Kapur. Program Studi Pendidikan Biologi Jurusan Pendidikan Matematika Dan Ilmu Pengetahuan Alam Fakultas Keguruan Dan Ilmu Pendidikan. Universitas Sanata Dharma: Yogyakarta.

Rani Farida dan M. A. Chozin .2015. Pengaruh Pemberian Cendawan Mikoriza
Arbuskula (CMA) dan Dosis Pupuk Kandang Ayam terhadap Pertumbuhan Dan Produksi Jagung (Zea mays L.)

Sargiman Gatot $\mathcal{E}$ Tiurma Wiliana Susanti Panjaitan 2013. Pengaruh Penggunaan Pupuk Organik Hayati Terhadap Sifat Fisika Tanah Di Kecamatan Pare Kabupaten Kediri. UNTAG Surabaya. Jurnal Agroknow Vol 1 No 1 Tahun 2013

Silalahi, Ulber. 2015. Metode Penelitian Sosial Kuantitatif. Bandung: PT. Refika Aditama. Hlm. 372.

Sudiarti Diah. 2018. Pengaruh Pemberian Cendawan Mikoriza Arbuskula (Cma) Terhadap Pertumbuhan Kedelai Edamame (Glycin Max). Jurnal SainHealth Vol.2 No.2 Edisi September 2018

Suliasih, Sri Widawati. 2015. Peningkatan Hasil Jagung Dengan Menggunakan Pupuk Organik Hayati (POH). Pros Sem Nas Masy Biodiv Indon.

Tjahjo Purtomo, dkk. 2014. Pengaruh Penggunaan Pupuk Organik Hayati Terhadap Sifat Kimia Tanah Pertanian Di Kecamatan Pare Kabupaten Kediri. Jurnal Agroknow Vol. 2 No. 1, Februari 2014 